\title{
Penerapan Metode Economical Order Quantity Untuk Sistem Stok Barang Penggudangan dengan menggunakan teknologi Radio Frequency Identification
}

\author{
Teddy Istanto $\mathrm{a}^{*}$ \\ ${ }^{a}$ Fakultas Teknik, Universitas Musamus, Merauke.
}

Naskah Diterima : 15 September 2016; Diterima Publikasi : 6 Mei 2017

DOI: $10.21456 /$ vol7iss1pp59-65

\begin{abstract}
The application of Economical Order Quantity method to stock warehouse system by using Radio Frequency Identification technology can provide information that can minimize stock availability in real time. The research aims to develop the stock system using the methods of Economical Order Quantity, Reorder Point and Radio Frequency Identification technology. Computation of Economical Order Quantity is used per month with variables covering amount of raw material, ordering cost and storage cost. Reorder Point computation using lead time variable, raw material usage and safety stock. Safety stock is used if there is a delay in delivery of goods from suppliers, so it does not run out of raw materials and the company can still operate. The inventory data is obtained from transactions of incoming and outgoing goods which are recorded automatically when passing through Radio Frequency Identification reader. The computation of Economical Order Quantity, Reorder Point produces safety stock as output stock system. With the stock of goods in accordance with the fulfillment of Safety stock, then there is no delay in the delivery of goods from suppliers, so it does not run out of raw materials, after determination of the value of re-ordering.
\end{abstract}

Keywords: Economical Order Quantity; Reorder Point; safety stock; Radio Frequency Identification

\begin{abstract}
Abstrak
Penerapan metode Economical Order Quantity untuk sistem stok barang pergudangan dengan menggunakan teknologi Radio Frequency Identification dapat memberikan informasi yang dapat meminimumkan ketersediaan stok barang secara real time. Penelitian ini bertujuan untuk mengembangkan sistem stok barang menggunakan metode Economical Order Quantity, Reorder Point dan teknologi Radio Frequency Identification. Perhitungan Economical Order Quantity dilakukan per bulan dengan variabel meliputi jumlah bahan baku, biaya pemesanan dan biaya penyimpanan. Perhitungan Reorder Point menggunakan variabel lead time, penggunaan bahan baku dan safety stock. Safety stock digunakan jika terjadi keterlambatan pengiriman barang dari supplier, sehingga tidak terjadi kehabisan bahan baku dan perusahaan tetap dapat beroperasi. Data stok barang diperoleh dari transaksi barang keluar dan transaksi barang masuk yang dicatat otomatis saat melewati Radio Frequency Identification reader. Hasil perhitungan Economical Order Quantity, Reorder Point menghasilkan safety stock sebagai outpout sistem stok barang. Dengan stok barang sesuai dengan dipenuhinya Safety stock, maka tidak terjadi keterlambatan pengiriman barang dari supplier, sehingga tidak terjadi kehabisan bahan baku, setelah ditentukannya nilai pemesanan kembali.
\end{abstract}

Kata kunci : Economical Order Quantity; Reorder Point; safety stock; Radio Frequency Identification

\section{Pendahuluan}

Gudang merupakan bagian penting dalam sebuah perusahaan yang berfungsi untuk menyimpan barang, sedangkan pergudangan merupakan kegiatan atau aktivitas menyimpan barang. Tujuan manajemen pergudangan adalah untuk menentukan jadwal produksi dengan tingkat persediaan yang terbatas atau menyarankan kebijakan pengisian bahan baku untuk memenuhi pesanan produksi (Yang dan Wee,

\footnotetext{
*) Penulis korespondensi: teddyistanto@gmail.com
}

2002). Gudang dan pergudangan penting bagi perusahaan karena dapat mempengaruhi pendapatan perusahaan. Sistem pergudangan yang kurang baik dapat menyebabkan adanya barang kadaluarsa, kehilangan barang dan lain sebagainya yang pada akhirnya mengurangi pendapatan perusahaan. Pergudangan yang baik adalah pergudangan yang memiliki sistem pelayanan yang baik. Sistem pelayanan yang baik mencakup adanya jaminan 
keamanan, kemudahan akses informasi keluar, informasi masuk, dan penyimpanan barang, serta kesesuaian kondisi lingkungan fisik bagi barang yang disimpan (Warman, 2004).

Perkembangan teknologi Radio Frequensi Identification (RFID) dewasa ini sangat pesat dan banyak digunakan di berbagai bidang untuk membantu dalam pengidentifikasian suatu objek. RFID memiliki karekteristik dapat melakukan pendaftaran secara massal, identifikasi tanpa berhadapan langsung dengan objek yang dibaca, menghilangkan kesalahan identifikasi dari setiap objek, memiliki penyimpanan data pada objek, dan ketahanan terhadap pengaruh-pengaruh lingkungan (Shepard, 2005). RFID memiliki kelebihan dari pada teknologi pengidentifikasi sebelumnya, seperti barcode. Kelebihan RFID diantaranya mampu membaca suatu objek data dengan ukuran tertentu tanpa melalui kontak langsung (contacless) dan tidak harus sejajar dengan objek yang dibaca, selain dapat menyimpan informasi pada tag RFID sesuai dengan kapasitasnya penyimpanan (Tarigan, 2004). Teknologi RFID banyak dimanfaatkan untuk membantu permasalahan yang berkaitan dengan pengindeksian suatu objek seperti identifikasi barang pada gudang atau tracking untuk perekaman suatu objek.

Persediaan berkaitan dengan penyimpanan bahan baku/barang yang bertujuan untuk menunjang kelancaran sistem produksi atau kegiatan bisnis yang dilakukan oleh sebuah perusahaan. Persediaan dapat diartikan sebagai barang-barang yang disimpan untuk digunakan atau dijual pada masa atau periode yang akan datang. Persediaan terdiri dari persediaan bahan baku, persediaan bahan setengah jadi dan persediaan barang jadi. Persediaan bahan baku dan bahan setengah jadi disimpan sebelum digunakan atau dimasukkan ke dalam proses produksi, sedangkan persediaan barang jadi atau barang dagangan disimpan sebelum dijual atau dipasarkan (Ristono, 2009).

Penelitian ini bertujuan untuk mengembangkan sistem stok barang menggunakan metode Economical Order Quantity (EOQ), Reorder Point (ROP) dan teknologi RFID. EOQ digunakan sebagai metode dalam pengambilan keputusan, yaitu menentukan jumlah jumlah pembelian ekonomis yang dilakukan pada setiap kali pembelian. Dengan $E O Q$, jumlah pembelian bahan baku dan barang, biaya pemeliharaan barang di gudang serta biaya pemesanan setiap tahun dapat dibuat minimum (Subagyo, 2000). Banyak perusahaan yang menggunakan sistem persediaan pemesanan berbasis $E O Q$ untuk membeli bahan baku (Wu dan Low, 2003).

Metode EOQ digunakan karena pembelian dengan menggunakan metode Just in Time (JIT) tidak selalu berhasil. Metode JIT adalah cara produksi yang menentukan jumlahnya hanya berdasarkan atas jumlah barang yang benar-benar akan dijual atau diperlukan dan tidak ada sisa maupun persediaan. Model JIT ini tidak dapat menjelaskan kebijakan yang diambil pada banyak perusahaan (Fazel et al., 1998). Jika pada metode $E O Q$ biaya pemesanan dilakukan untuk mengetahui tingkat pemesanan yang paling ekonomis untuk mengefisiensikan biaya, sedangkan pada metode JIT pemesanan akan dilakukan kembali setelah ada order dari pelanggan. Penggunaan metode EOQ dalam pengambilan keputusan pembelian bahan baku akan mampu mengurangi terjadinya out of stock sehingga proses produksi dapat berjalan dengan lancar sehingga mewujudkan efisiensi persediaan bahan baku. Penghematan biaya penyimpanan bahan baku dan penggunaan gudang juga dapat dilakukan dengan metode ini. Begitu juga risiko yang timbul karena persediaan bahan baku yang menumpuk di gudang dapat pula diatasi dengan memanfaatkan metode ini.

\section{Kerangka Teori}

\subsection{Radio Frequensi Identification}

Radio Frequensi Identification (RFID) merupakan pengembangan teknologi untuk pengambilan/ pengenalan/ identifikasi objek secara otomatik. RFID menggunakan frekuensi radio untuk mengirimkan informasi atau data antara $R F I D$ tag dengan RFID reader, sehingga tidak diperlukan kontak fisik diantara keduanya untuk dapat berkomunikasi. Pada bisnis Ritel, RFID dipergunakan untuk melakukan tracking dan melakukan pencatatan terhadap seluruh inventori.

Sistem RFID memungkinkan komunikasi antara produk-produk yang telah ditag dengan chip RFID dengan RFID reader dan dengan Server lokal. Cara kerja sistem secara keseluruhan menyerupai dengan penggunaan barcode label dan barcode scanner, tetapi jauh lebih mudah, praktis dan memuaskan, karena petugas tidak perlu melakukan scanning item satu-persatu, karena pada saat pelanggan melewati scanner (RFID reader) seluruh item akan langsung terdeteksi atau dihitung secara bersamaan.

Sistem RFID terdiri dari tiga komponen, yaitu tag, antena, pembaca RFID. Tag adalah perangkat yang menyimpan informasi untuk identifikasi objek. Tag RFID sering juga disebut sebagai transponder. Antena adalah alat untuk mentransmisikan sinyal frekuensi radio antara pembaca $R F I D$ dengan tag $R F I D$. Pembaca $R F I D$ merupakan perangkat yang kompatibel dengan tag $R F I D$ yang akan berkomunikasi secara wireless dengan tag. Tag dan pembaca $R F I D$ dilengkapi dengan antena sehingga dapat menerima dan memancarkan gelombang elektromagnetik.

Dalam proses akuisisi data barang datang akan ditempeli tag RFID yang berisi kode barang masuk, kode RFID, supplier, barang, jumlah, harga beli, tanggal, biaya pemesanan. Barang yang masuk ke 
gudang akan melewati RFID Reader yang berfungsi untuk membaca data pada tag RFID dan data jumlah barang yang masuk akan disimpan pada komputer server, sehingga dapat diketahui berapa banyak jumlah stok barang yang masuk, dan jumlah stok pada gudang. Barang yang akan keluar dari gudang akan melewati RFID reader, data barang yang keluar akan dikirimkan ke server sehingga dapat diketahui jumlah barang yang keluar. Data barang yang tersimpan pada server dapat diakses melalui komputer secara real time sehingga mempermudah untuk mengetahui stok dan ketersediaan barang pada gudang seperti ditunjukan pada Gambar 1.

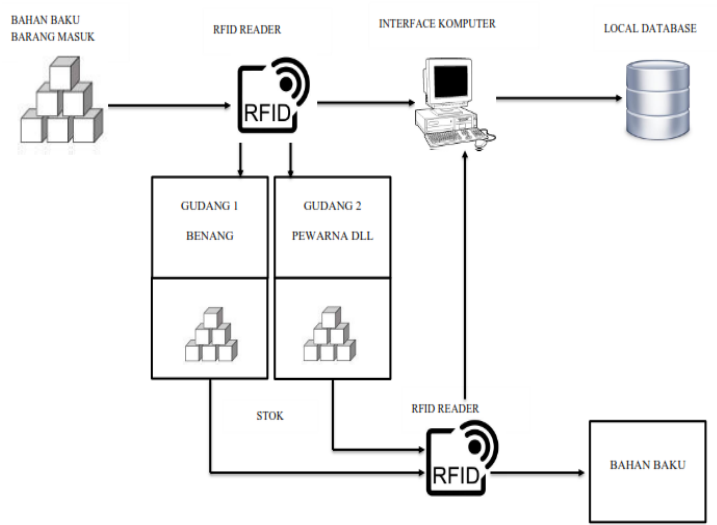

Gambar 1 Skema akuisisi data menggunakan RFID pada gudang bahan baku Tenun.

\subsection{Economical Order Quantity.}

Economical Order Quantity (EOQ) merupakan metode manajemen persediaan yang digunakan untuk menghitung minimalisasi total biaya persediaan berdasarkan persamaan tingkat atau titik equlibrium kurva biaya simpan dan biaya pesan (Divianto, 2011). Metode EOQ mengasumsikan permintaan secara pasti dengan pemesanan yang dibuat secara konstan serta tidak adanya kekurangan persediaan (Rangkuti, 2007).

Asumsi yang harus dipenuhi dalam metode $E O Q$ (Subagyo, 2000) yaitu: (1) Jumlah kebutuhan barang selama setahun dapat diperkirakan dan kebutuhan barang sepanjan tahun relatif stabil; (2) Hanya ada dua macam biaya yang relevan, yaitu biaya pemesanan dan biaya pemeliharaan barang; (3) Biaya pemesanan untuk setiap kali pemesanan besarnya selalu sama (4) Biaya pemeliharaan barang setiap unit setiap tahun selalu sama. Biaya pemeliharaan barang ini bersifat variabel, tergantung pada jumlah barang yang disimpan dan lama waktu penyimpanan; (5) Usia barang relatif lama, tidak cepat menjadi aus, busuk atau rusak; (6) Harga barang setiap unit barang selalu sama atau stabil; (7) Tidak ada kendala atau batasan jumlah barang yang dapat dipesan.

Pada saat barang datang, jumlah persediaan sama dengan jumlah barang yang dipesan (Q), tetapi karena setiap hari dipakai, jumlah persedian barang semakin menipis, yang akhirnya habis. Perhitungan $E O Q$ merupakan proses perhitungan yang melibatkan kebutuhan bahan baku selama satu bulan $(O)$, biaya pemesanan bahan baku setiap kali pesan $(S)$, serta biaya pemeliharaan barang setiap unitnya setiap bulan $(C)$. Proses perhitungan menggunakan EOQ ini dilakukan dengan Persaman (1).

$$
E O Q=\sqrt{\frac{205}{C}}
$$

dimana $\mathrm{O}$ adalah kebutuhan bahan baku, $\mathrm{S}$ adalah biaya pemesanan bahan baku setiap kali pesan, dan $\mathrm{C}$ adalah biaya pemeliharaan barang setiap unitnya.

Rata-rata jumlah stok persediaan didapat dari jumlah kuantitas yang dipesan dibagi dua. Hal ini disebabkan jumlah pemesanan yang baru datang akan mencapai titik maksimal stok dan ketika barang mulai keluar dari gudang, sehingga jumlah stok persediaan akan berkurang sampai titik terendah stok. Dengan demikian untuk menghitung rata-rata adalah dengan mencari titik tengah keduanya dengan membagi dua.

Semakin banyak jumlah barang pada setiap kali pembelian, semakin besar rata-rata barang yang ada digudang. Semakin banyak barang digudang semakin tinggi biaya pemeliharaan. Semakin banyak jumlah barang setiap kali pembelian, semakin jarang dilakukan pembelian. jika jumlah kebutuhan barang setiap tahun tetap berakibat biaya pemesanan semakin mahal (Subagyo, 2000).

\subsection{Safety Stock}

Safety stock merupakan persediaan barang minimum untuk menghindari terjadinya kehabisan atau kekurangan barang. Perhitungan Safety Stock merupakan proses perhitungan yang melibatkan pemakaian maksimum bahan baku selama satu bulan $\left(P_{\max }\right)$, pemakaian rata-rata bahan baku $\left(P_{\text {rata }}\right)$, Waktu yang dibutuhkan antara bahan baku dipesan hingga sampai di perusahaan (LT). Proses perhitungan Safety Stock dilakukan dengan persaman sebagai berikut :

$$
S S=\left(P_{\max }-P_{\text {rata }}\right) L T
$$

\subsection{Reorder point}

Selain mengetahui berapa banyak barang yang akan dipesan, perusahaan juga perlu tahu kapan untuk memesan barang kembali. Pemesanan kembali dilakukan pada saat jumlah barang yang ada pada gudang berada pada titik pemesanan reorder point (ROP) (Horne dan Wachowicz, 2008). Faktor-faktor yang mempengaruhi ROP (Divianto, 2011) adalah (1) Lead time, yang merupakan waktu yang dibutuhkan antara bahan baku dipesan hingga sampai di perusahaan; (2) Tingkat pemakaian bahan baku rata-rata persatuan waktu tertentu; (3) Persediaan pengaman (safety stock) yaitu jumlah persediaan bahan minimum yang harus dimiliki oleh 
perusahaan untuk menjaga kemungkinan keterlambatan datangnya bahan baku.

Perhitungan $R O P$ merupakan proses perhitungan yang melibatkan waktu yang dibutuhkan antara bahan baku dipesan hingga sampai di perusahaan $(L)$, tingkat pemakaian bahan baku rata-rata persatuan waktu tertentu $(Q)$, dan persediaan minimum untuk menghindari terjadinya kekurangan barang (SS). Proses perhitungan $R O P$ dilakukan dengan persaman sebagai berikut :

$$
R O P=L Q+S S
$$

\section{Metodologi}

Penelitian ini menggunakan data dari Perusahaan $\mathrm{X}$ pada tahun 2016 untuk kebutuhan bahan baku tenun untuk satu bulan meliputi jumlah persediaan bahan baku, produksi, dan jumlah pemesanan bahan baku. Jumlah jenis barang yang diperlukan sebanyak 48 jenis barang. Selain data tersebut juga digunakan data-data pendukung lain yang penggudangan. Rincian data diberikan pada Tabel 1 (dengan hanya mengambil jenis barang sebanyak 13, sebagai bagian jenis barang sebanyak 48). Sedangkan peralatan yang digunakan dalam penelitian ini adalah satu unit mikrokomputer, RFID, Sistem Operasi Windows 7, PHP dan MySql dalam xampp 2.5.

Perancangan sistem menggunakan Data Flow Diagram (DFD) yang terdiri dari $D F D$ level $0, D F D$ level 1 dan $D F D$ level 2. Perancangan $D F D$ bertujuan untuk menggambarkan alur sistem secara terperinci dalam sistem persediaan bahan baku benang. a. DFD level 0 menggambarkan sistem secara keseluruhan beserta aliran data sebagai masukan dan keluaran.

b. $D F D$ level 1 menggambarkan diagram yang terdiri dari tiga proses yaitu proses input data barang, proses pergudangan, proses perhitungan stok. Proses input data barang menghasilkan data barang yang disimpan pada tabel barang masuk. Proses pergudangan menyimpan seluruh data barang masuk ke tabel barang yang digunakan untuk proses perhitungan stok.

c. $D F D$ level 2 menggambarkan proses yang dijabarkan dari proses 3.0 perhitungan stok menjadi tiga proses yaitu proses perhitungan safety stock, proses perhitungan ROP, proses perhitungan $E O Q$. Pada proses perhitungan safety stok, input diperoleh dari tabel barang dan output berupa safety stock digunakan untuk proses perhitungan ROP. Pada proses perhitungan EOQ untuk didapatkan jumlah pembelian bahan baku yang ekonomis.

Kerangka sistem stok barang didesain menggunakan metode $E O Q$, dan untuk sistem stok barang pergudangan dengan menggunakan teknologi RFID. Data yang telah dikumpulkan akan dilakukan proses pengolahan dengan menggunakan metode $E O Q$ dan teknologi RFID. Data yang dihasilkan dari pembacaan atau pengambilan data dari tag RFID dan $R F I D$ reader pada item bahan baku, meliputi jumlah persediaan bahan baku, produksi, dan jumlah pemesanan bahan baku.

Tabel 1. Bahan baku tenun

\begin{tabular}{lllcccccc}
\hline No & Jenis & Nama Barang & $\begin{array}{c}\text { Kebutuhan per } \\
\text { BulBn(Unit) }\end{array}$ & $\begin{array}{c}\text { biaya } \\
\text { pesan/kg }\end{array}$ & $\begin{array}{c}\text { biaya pesan } \\
(\mathrm{Rp})\end{array}$ & Harga (Rp) & $\begin{array}{c}\text { biaya } \\
\text { simpan } \\
(\mathrm{Rp})\end{array}$ & $\begin{array}{c}\text { lead } \\
\text { time }\end{array}$ \\
\hline 1 & Benang & Benang 64 & 45 & 16.000 & 720.000 & 570.000 & 57.000 & 5 \\
2 & Benang & Benang 80 & 45 & 16.000 & 720.000 & 670.000 & 67.000 & 5 \\
3 & Pewarna & Black Sulfur & 25 & 11.000 & 275.000 & 65.000 & 6.500 & 2 \\
4 & Pewarna & Garem Merah & 25 & 11.000 & 275.000 & 110.000 & 11.000 & 2 \\
5 & Pewarna & Garem Biru & 25 & 11.000 & 275.000 & 110.000 & 11.000 & 2 \\
6 & Pewarna & Soda Api & 25 & 11.000 & 275.000 & 14.000 & 1.400 & 2 \\
7 & Pewarna & Hidro Sulfid & 25 & 11.000 & 275.000 & 30.000 & 3.000 & 2 \\
8 & Pewarna & Green B & 10 & 11.000 & 110.000 & 470.000 & 47.000 & 2 \\
9 & Pewarna & Salt GG & 10 & 11.000 & 110.000 & 120.000 & 12.000 & 2 \\
10 & Pewarna & Salt R & 10 & 11.000 & 110.000 & 120.000 & 12.000 & 2 \\
11 & Pewarna & ASBS & 10 & 11.000 & 110.000 & 120.000 & 12.000 & 2 \\
12 & Pewarna & ASBO & 10 & 11.000 & 110.000 & 120.000 & 12.000 & 2 \\
13 & Pewarna & ASG & 10 & 11.000 & 110.000 & 120.000 & 12.000 & 2 \\
\hline
\end{tabular}


Perhitungan menggunakan metode EOQ dilakukan dengan tahapan-tahapan sebagai berikut:

a. Langkah pertama:

Menentukan berapa jumlah bahan baku yang diperlukan selama 1 bulan. Jumlah kebutuhan bahan baku selama 1 bulan didapat dari total kebutuhan bahan baku yang digunakan perusahaan selama 1 bulan produksi perusahaan.

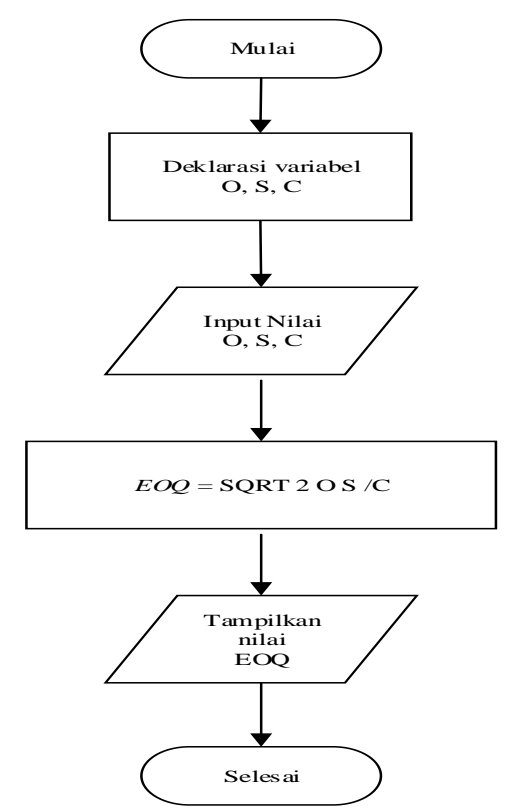

Gambar 2. Alur kerja Metode $E O Q$

b. Langkah kedua:

Menentukan biaya pemesanan setiap kali melakukan pemesanan bahan baku. Biaya pemesanan merupakan total biaya yang dikeluarkan dalam pemesanan barang. Biaya pemesanan tidak tergantung dari berapa jumlah yang dipesan, tetapi tergantung dari berapa kali pesanan dilakukan. Berapa biaya pemeliharaan barang setiap unit barang setiap bulan.

c. Langkah ketiga:

Biaya pemeliharaan bahan baku merupakan biaya yang dikeluarkan selama dilakukan penyimpanan bahan baku atau merawatan barang digudang. Biaya pemeliharaan ialah $10 \%$ dari harga bahan baku.

Alur kerja metode EOQ ditunjukan pada Gambar 2. Dalam sistem stok barang, barang masuk akan ditempeli tag RFID yang berisi kode barang masuk, kode RFID, supplier, barang, jumlah, harga beli, tanggal, biaya pemesanan. Barang yang masuk ke gudang akan melewati RFID Reader yang berfungsi untuk membaca data pada tag RFID dan data jumlah barang yang masuk akan disimpan pada komputer server, sehingga dapat diketahui berapa banyak jumlah stok barang yang masuk, dan jumlah stok pada gudang. Barang yang akan keluar dari gudang akan melewati RFID reader, data barang yang keluar akan dikirimkan ke server sehingga dapat diketahui jumlah barang yang keluar. Data barang yang tersimpan pada server akan dilakukan perhitungan average inventory dan optimal order quantity, hasil dari proses perhitungan akan ditampilkan berupa, daftar barang yang akan dibeli, total biaya pembelian barang, daftar barang dan stok barang secara realtime, sehingga mempermudah untuk mengetahui stok dan ketersediaan barang pada gudang

Tabel 2 Biaya pemesanan sebelum menggunakan EOQ

\begin{tabular}{lccccc}
\hline \multicolumn{1}{c}{ Nama Barang } & $\begin{array}{c}\text { Stok } \\
(\mathrm{pcs})\end{array}$ & $\begin{array}{c}\text { Biaya Pesan } \\
\text { (Rp/pesan) }\end{array}$ & $\begin{array}{c}\text { Biaya simpan } \\
\text { (Rp/bulan) }\end{array}$ & $\begin{array}{c}\text { Frekuensi Pesan } \\
\text { (Kali/bulan) }\end{array}$ & $\begin{array}{c}\text { Biaya Pemesanan } \\
\text { (Rupiah) }\end{array}$ \\
\hline Benang 64 & 45 & 720.000 & 57.000 & 1 & 720.000 \\
Benang 80 & 45 & 720.000 & 67.000 & 1 & 720.000 \\
Black Sulfur & 25 & 275.000 & 6.500 & 1 & 275.000 \\
Garem Merah & 25 & 275.000 & 11.000 & 1 & 275.000 \\
Garem Biru & 25 & 275.000 & 11.000 & 1 & 275.000 \\
Soda Api & 25 & 275.000 & 1.400 & 1 & 275.000 \\
Hidro Sulfid & 25 & 275.000 & 3.000 & 1 & 275.000 \\
Green B & 25 & 275.000 & 47.000 & 1 & 275.000 \\
Salt GG & 10 & 110.000 & 12.000 & 1 & 110.000 \\
Salt R & 10 & 110.000 & 12.000 & 1 & 110.000 \\
ASBS & 10 & 110.000 & 12.000 & 1 & 110.000 \\
ASBO & 10 & 110.000 & 12.000 & 1 & 110.000 \\
ASG & 10 & 110.000 & 12.000 & 1 & 110.000 \\
\hline
\end{tabular}


Tabel 3 Biaya pemesanan setelah menggunakan EOQ.

\begin{tabular}{lccccc}
\hline \multicolumn{1}{c}{ Nama Barang } & $\begin{array}{c}\text { Stok } \\
(\mathrm{pcs})\end{array}$ & $\begin{array}{c}\text { Biaya Pesan } \\
\text { (Rp/pesan) }\end{array}$ & $\begin{array}{c}\text { Biaya simpan } \\
\text { (Rp/bulan) }\end{array}$ & $\begin{array}{c}\text { Frekuensi Pesan } \\
\text { (Kali/bulan) }\end{array}$ & $\begin{array}{c}\text { Biaya Pemesanan } \\
\text { (Rupiah) }\end{array}$ \\
\hline Benang 64 & 45 & 720.000 & 57.000 & 1,33 & 957.600 \\
Benang 80 & 45 & 720.000 & 67.000 & 1,45 & 1.044 .000 \\
Black Sulfur & 25 & 275.000 & 6.500 & 0,54 & 148.500 \\
Garem Merah & 25 & 275.000 & 11.000 & 0,71 & 195.250 \\
Garem Biru & 25 & 275.000 & 11.000 & 0,71 & 195.250 \\
Soda Api & 25 & 275.000 & 1.400 & 0,25 & 68.750 \\
Hidro Sulfid & 25 & 275.000 & 3.000 & 0,37 & 101.750 \\
Green B & 25 & 275.000 & 47.000 & 1,46 & 401.500 \\
Salt GG & 10 & 110.000 & 12.000 & 0,74 & 81.400 \\
Salt R & 10 & 110.000 & 12.000 & 0,74 & 81.400 \\
ASBS & 10 & 110.000 & 12.000 & 0,74 & 81.400 \\
ASBO & 10 & 110.000 & 12.000 & 0,74 & 81.400 \\
ASG & 10 & 110.000 & 12.000 & 0,74 & 81.400 \\
\hline
\end{tabular}

Tabel 4. Hasil Perhitungan EOQ, ROP dan Safety Stock menggunakan perangkat lunak

\begin{tabular}{|c|c|c|c|c|c|c|c|c|}
\hline $\begin{array}{c}\text { Kode } \\
\text { Barang }\end{array}$ & $\begin{array}{l}\text { Nama } \\
\text { Barang }\end{array}$ & $\begin{array}{l}\text { Kebutuhan } \\
\text { perbulan }\end{array}$ & Stok & $\begin{array}{l}\text { Jumlah } \\
\text { barang } \\
\text { keluar }\end{array}$ & Nilai EOQ & Safety Stock & Nilai ROP & Status \\
\hline KB01 & Benang 64 & 45 unit & 43 unit & 4 unit & 34 unit & 25 unit & 32.5 unit & Stok aman \\
\hline KB02 & Benang 80 & 45 unit & 43 unit & 2 unit & 31 unit & 25 unit & 32.5 unit & Stok aman \\
\hline KB03 & $\begin{array}{l}\text { Black } \\
\text { sulfur }\end{array}$ & 25 unit & 24 unit & 1 unit & 46 unit & 4 unit & 5.67 unit & Stok aman \\
\hline KB04 & $\begin{array}{l}\text { Garam } \\
\text { merah }\end{array}$ & 25 unit & 24 unit & 1 unit & 35 unit & 4 unit & 5.67 unit & Stok aman \\
\hline KB05 & Garam biru & 25 unit & 24 unit & 1 unit & 35 unit & 4 unit & 5.67 unit & Stok aman \\
\hline KB06 & Soda api & 25 unit & 24 unit & 1 unit & 99 unit & 4 unit & 5.67 unit & Stok aman \\
\hline KB07 & Hidro sulfid & 25 unit & 24 unit & 1 unit & 21 unit & 4 unit & 5.67 unit & Stok aman \\
\hline KB08 & Green B & 25 unit & 24 unit & 1 unit & 17 unit & 4 unit & 5.67 unit & Stok aman \\
\hline KB09 & Ssalt GG & 10 unit & 9 unit & 1 unit & 14 unit & 4 unit & 4.67 unit & Stok aman \\
\hline KB10 & Salt R & 10 unit & 0 unit & 10 unit & 14 unit & 4 unit & 4.67 unit & $\begin{array}{l}\text { Stok } \\
\text { kosong } \\
\text { silahkan } \\
\text { pesan } \\
\text { kembali }\end{array}$ \\
\hline KB11 & ASBS & 10 unit & 8 unit & 2 unit & 14 unit & 4 unit & 4.67 unit & Stok aman \\
\hline KB12 & ASBO & 10 unit & 4 unit & 6 unit & 14 unit & 4 unit & 4.67 unit & $\begin{array}{l}\text { Stok kurang } \\
\text { silahkan } \\
\text { pesan } \\
\text { kembali }\end{array}$ \\
\hline KB13 & ASG & 10 unit & 9 unit & 1 unit & 14 unit & 4 unit & 4.67 unit & Stok aman \\
\hline
\end{tabular}

\section{Hasil dan Pembahasan}

Sistem stok barang dibangun dengan metode EOQ, ROP dan teknologi RFID, serta menggunakan $P H P$ dan My SQL. Sebagai masukan utama sistem adalah jumlah persediaan bahan baku, produksi, dan jumlah pemesanan bahan baku. Keluaran dari sistem stok barang meliputi jumlah stok barang yang dapat langsung dikontrol sehingga dapat diketahui secara real time. Dalam proses istem stok barang, data yang telah dikumpulkan dilakukan proses pengolahan dengan metode $E O Q$.

Data yang digunakan dalam proses perhitungan $E O Q$ dan safety stock menggunakan data bahan baku tenun selama 1 (satu) bulan. Data bahan baku yang digunakan sebagaimana tercantum pada Tabel 1. Penggunaan metode EOQ berfungsi untuk menghitung jumlah pembelian yang paling ekonomis, informasi untuk meminumkan terjadinya kehabisan stok bahan baku pada gudang bahan baku. Berdasarkan hasil perhitungan dengan metode EOQ, dapat dibandingkan hasil perhitungan sebelum dan sesudah menggunakan EOQ. Biaya pemesanan sebelum menggunakan EOQ diberikan pada Tabel2, sedangkan sesudah menggunakan EOQ diberikan pada Tabel 3. Dari hasil perhitungan tersebut terlihat jelas bedanya, dan jika frekuensi untuk sesudah menggunakan EOQ dibulatkan, maka biaya pemesanan setelah mengggunakan EOQ semakin sedikit. 
Dengan menggunakan langkah-langkah dalam perhitungan EOQ, ROP dan Safety Stock kemudian dilakukan percobaan dengan kategori data yang berbeda dan jumlah data yang berbeda maka dihasilkan perhitungan EOQ, ROP dan Safety Stock seperti pada Tabel 4. Hasil perhitungan EOQ, ROP dan Safety Stock didapat data laporan sebagai berikut, Barang dengan kode barang KB01 dengan nama barang benang 64 , kebutuhan perbulan sebanyak 45 unit, pembelian yang dianjurkan oleh EOQ untuk setiap kali pembelian adalah sebanyak 34 unit, dengan nilai Safety Stock atau stok pengamanan sebanyak 25 unit, safety stock ini digunakan jika terjadi keterlambatan pengiriman barang dari supplier, sehingga tidak terjadi kehabisan bahan baku, sehingga perusahaan tetap dapat peroperasi. Sedangkan nilai $R O P$ atau pemesanan kembali adalah sebanyak 32,5 unit, dimana ketika jumlah stok barang yang semula sebanyak 45 unit telah mengalami pengurangan sehingga tersisa 32,5 unit, maka akan dilakukan pemesanan lagi terhadap barang tersebut.

Pengujian sistem peringatan stok barang dilakukan dengan melakukan uji kesesuaian antara nilai $R O P$ dan status peringatan. Sistem peringatan stok barang akan secara otomatis melakukan peringatan apabila memenuhi salah satu atau lebih kondisi-kondisi aturan uji: (1) Jika nilai stok barang lebih besar dari atau sama dengan nilai $R O P$ maka status stok aman dengan warna hijau; 92) Jika nilai stok barang lebih kecil dari nilai $R O P$ maka status stok kurang dengan warna kuning. Jika status item barang stok kurang maka bagian pembelian barang akan melakukan pemesanan kembali dengan melihat jumlah pemesanan pada nilai $E O Q$ dan nilai $R O P$, sehingga pemesanan barang kembali tepat waktu dan tidak terjadi penumpukan dan kekurangan stok; (3) Jika nilai stok barang sama dengan 0 maka status stok kosong dengan warna merah. Jika status item barang stok kosong maka bagian pembelian bahan baku harus melakukan pemesanan kembali dengan melihat jumlah pemesanan pada nilai $E O Q$ dan nilai $R O P$ sehingga pemesanan barang kembali tepat waktu dan tidak terjadi penumpukan dan kekurangan stok. Berdasarkan hasil pengujian, semua perhitungan secara komputasi dalam sistem stok barang semuanya sama.

\section{Kesimpulan}

Penerapan metode $E O Q$ untuk sistem stok barang pergudangan dengan menggunakan teknologi $R F I D$ dapat digunakan untuk menghasilkan informasi untuk meminumkan terjadinya kehabisan stok bahan baku pada gudang bahan baku, memberikan laporan ketersediaan barang secara real time serta menghasilkan status barang aman, tidak aman sehingga dapat dilakukan pemesanan kembali.
Penggunaan teknologi RFID untuk pergudangan dapat membantu menangani permasalahan identifikasi dan pencarian barang pada gudang serta memberikan laporan ketersediaan barang secara real time.

Penggunaan metode EOQ berfungsi untuk menghitung jumlah pembelian yang paling ekonomis, dan memberikan informasi untuk meminumkan terjadinya kehabisan stok bahan baku pada gudang bahan baku. Hasil perhitungan dengan metode EOQ, jumlah biaya pemesanan sesudah menggunakan EOQ lebih efisien jika dibandingkan dengan jumlah biaya pemesanan sebelum mengggunakan EOQ.

\section{Daftar Pustaka}

Divianto, 2011. Tinjauan Atas Planning, Replenishment (Skenario) dan activities Inventory Control, Jurnal Ekonomi dan Informasi Akuntansi, Politeknik Negeri Sriwijaya Palembang.

Fazel, F., Fischer, K.P., Gilbert, E.W., 1998. JIT purchasing vs. EOQ with a price discount: An analytical comparison of inventory costs, International Journal of Production Economics 54 (1), 101-109.

Horne, V.C.J., Wachowicz, M.J., 2008. Fundamentals of Financial Management 13th Editio, Prentice-Hall, Inc.

Rangkuti, F., 2007. Riset Pemasaran, Gramedia Pustaka Utama, Jakarta.

Ristono, A., 2009. Manajemen Persediaan, Graha Ilmu, Yogyakarta.

Sphicas, G.P., 2014. Generalized EOQ formula using a new parameter: Coefficient of backorder attractiveness, Int. J. Production Economics 115.

Shepard, S., 2005. Radio Frequency Identification, McGraw-Hill, New York.

Subagyo, P., 2000. Manajemen Operasi Edisi Pertama, BPFE, Yogyakarta.

Tarigan, Z.J.H., 2004. Integrasi teknologi RFID dengan teknologi Erp untuk otomasisasi data (Studi kasus pada gudang barang jadi perusahaan furniture. Jurnal teknik Industri 6 (2).

Warman, J., 2004. Manajemen pergudangan, Pustaka Sinar Harapan, Jakarta.

Wu, M., Low, S.P., 2003. Just-in-time (JIT) management for ready mixed concrete suppliers in Singapore, Proceedings of the Joint International Symposium of CIB W55, W65 and W107, Singapore, pp. 175-186.

Yang, P.C., Wee, H.M., 2002. A single-vendor and multiple-buyers production -Inventory policy for a deteriorating item, European Journal of Operational Research, 143, 570-581. 